\title{
A COMPARATIVE STUDY OF PERIPHERALLY INSERTED SILICONE CATHETERS FOR PARENTERAL NUTRITION
}

\author{
Allan S. MacDonald, Surya K.P. Master, and Emerson A. Moffitto
}

INTRAVENOUS INFUSION of amino acids and lipids has become a standard technique in the maintenance of nutrition in surgical patients who, for one reason or another, are unable to eat. To provide the total daily calorie requirements glucose and amino acids must be given as hypertonic solutions which thus cannot be infused in peripheral veins. Access to the central venous system is therefore necessary. Long plastic catheters inserted through peripheral veins such as the basilic or cephalic veins of the arm and thence into the superior vena cava, are associated with an inordinate incidence of phlebitis or thrombosis or both. Plastic catheters inserted percutaneously directly into the subclavian vein avoid this complication. More than anything else this has led to the rapid acceptance of total parenteral nutrition therapy. ${ }^{1}$

Plastic catheters are stiff, easily broken, and irritating to tissues. ${ }^{2}$ Numerous complications including catheter embolism, perforation of atrium or ventricle and mural thrombosis have been reported..$^{3-5}$ With increasing experience and careful technique these complications should be rare, ${ }^{6}$ but the existence of these problems has led to the increasing popularity of the recently introduced soft silicone elastomer subclavian catheter. $f$ Although the venous complications of this catheter have been almost nil, the hazards of subclavian puncture such as pneumothorax, haematoma, brachial plexus injury and inadvertent arterial puncture are still present.

In this study we compared two silicone elastomer catheters, one inserted peripherally and one through the subclavian vein, with two similar polyvinyl catheters for the delivery of parenteral infusion of hypertonic solutions. For additional comparison, a simple intravenous needle system was also evaluated.

\section{Materials, Methods and Patients}

Patients were allocated to one of five groups of twenty patients depending on the type of catheter or needle used. The first four groups received intravenous infusions of hypertonic glucose and amino acids (Aminosol ${ }^{\circledR}$, Amigen ${ }^{\circledR}$, or Travasol $\left.{ }^{\otimes}\right) \neq$ supplemented in about half the patients in each group by lipid infusate (Intralipid $\left.{ }^{\oplus}\right) \S$ (Table I). The fifth group received Intralipid ${ }^{\circledR}$ given by

'Departments of Surgery and Anaesthesia, Dalhousie University at the Victoria General Hospital, Halifax, Nova Scotia.

Address for correspondence: A.S. MacDonald, M.D., Dalhousie Clinical Research Centre, 5849 University Avenue, Halifax, Nova Scotia, Canada, B3H 4 H7.

† Vicra Division, Travenol Laboratories, Inc.

$\$$ Baxter Laboratories, Malton, Ontario.

\$Manufactured by Vitrum, Stockholm for Pharmacia (Canada) Ltd., Dorval, P.Q. 
TABLE I

Details - Patients And Solutions

\begin{tabular}{|c|c|c|c|c|}
\hline Intrasil & Centrasil & Intrafusor & Bard-i-cath & Butterfly \\
\hline $\begin{array}{l}23 \text { catheters } \\
\text { n } 20 \text { patients }\end{array}$ & $\begin{array}{l}20 \\
20\end{array}$ & $\begin{array}{l}20 \\
20\end{array}$ & $\begin{array}{l}20 \\
20\end{array}$ & $\begin{array}{l}20 \\
20\end{array}$ \\
\hline All patients: & Intralipid & \multicolumn{2}{|c|}{$\begin{array}{l}\text { hypertonic glucose and Aminosol } \\
\text { Amigen or Travasol }\end{array}$} & $\begin{array}{l}\text { All patients: } \\
\text { intralipid } \\
\text { only. }\end{array}$ \\
\hline
\end{tabular}

TABLE II

Detalls of Intravenous Catheters

\begin{tabular}{|c|c|c|c|c|}
\hline 1. Intrasil & 2. Centrasil & 3. Intrafusor & 4. Bard-i-cath & 5. Butterfly \\
\hline $\begin{array}{l}50.5 \mathrm{~cm} \\
\text { silicone } \\
\text { catheter } \\
\text { (Crank Unit) }\end{array}$ & $\begin{array}{l}22.9 \mathrm{~cm} \\
\text { silicone } \\
\text { catheter }\end{array}$ & $\begin{array}{l}54.3 \mathrm{~cm} \\
\text { polyvinyl } \\
\text { catheter }\end{array}$ & $\begin{array}{l}30.4 \mathrm{~cm} \\
\text { polyvinyl } \\
\text { catheter }\end{array}$ & $\begin{array}{l}2.5 \mathrm{~cm} \\
\text { steel } \\
\text { needle }\end{array}$ \\
\hline $\begin{array}{l}\text { 16-gauge } \\
\text { antecubital }\end{array}$ & $\begin{array}{l}\text { 16-gauge } \\
\text { subclavian }\end{array}$ & $\begin{array}{l}\text { 15-gauge } \\
\text { antecubital }\end{array}$ & $\begin{array}{l}\text { 15-gauge } \\
\text { subclavian }\end{array}$ & $\begin{array}{l}21 \text {-gauge } \\
\text { arm, hand }\end{array}$ \\
\hline
\end{tabular}

a short one inch stainless steel needle (Butterfy ${ }^{\circ}$ into a peripheral vein in the arm or hand. There were four different intravenous catheters (Table II).

The first catheter consists of a 16-gauge, $50.5 \mathrm{~cm}$ silicone elastomer catheter, with a steel spring stylet coiled within a plastic crank (Figure 1) with an attached slotted 14-gauge needle (Intrasil ${ }^{\circ} \uparrow$ (Figure 2). Following venipuncture of the basilic or cephalic vein in the usual manner, the crank is unwound threading the catheter through the slotted needle into the vein and thence into the superior vena cava (Figure 3 ).

The second catheter is a 16-gauge silicone elastomer central venous catheter, $22.9 \mathrm{~cm}$ in length, which is inserted percutaneously into the subclavian vein through a 14-gauge teflon introducer unit, consisting of a three-inch teflon catheter with a stainless steel removable trocar (Centrasili). Following puncture of the subclavian vein, the stainless steel trocar is removed and the catheter threaded into the vein through the teflon introducer which is then withdrawn so that it is outside the vein but under the skin.

The third unit is a 15-gauge, $54.34 \mathrm{~cm}$ long, central venous polyvinyl catheter (Intrafusor ${ }^{\circledR}$ ), $\$$ inserted through a 14-gauge needle by venipuncture of the basilic or cephalic vein of the arm.

The fourth catheter is a 15-gauge polyvinyl subclavian catheter (Bard-i-cath ${ }^{\circledR}$ ), $\|$ $30.4 \mathrm{~cm}$ long inserted by direct venipuncture of the subclavian vein with a 14-gauge needle through which the catheter is threaded.

The patients had a variety of illnesses, all of which precluded adequate oral nourishment. In the Intrasil 1 group there were 23 catheters inserted in 20 patients. In the other groups only one catheter was used for each patient.

\footnotetext{
-Abbott Laboratories, North Chicago, Illinois.

†Vicra Division, Travenol Laboratories, Inc.

$\ddagger$ Vicra Division, Travenol Laboratories, Inc.

\$Sorenson Research Co., Salt Lake City, Utah.

IIC.R. Bard Ltd., Sunderland, U.K.
} 


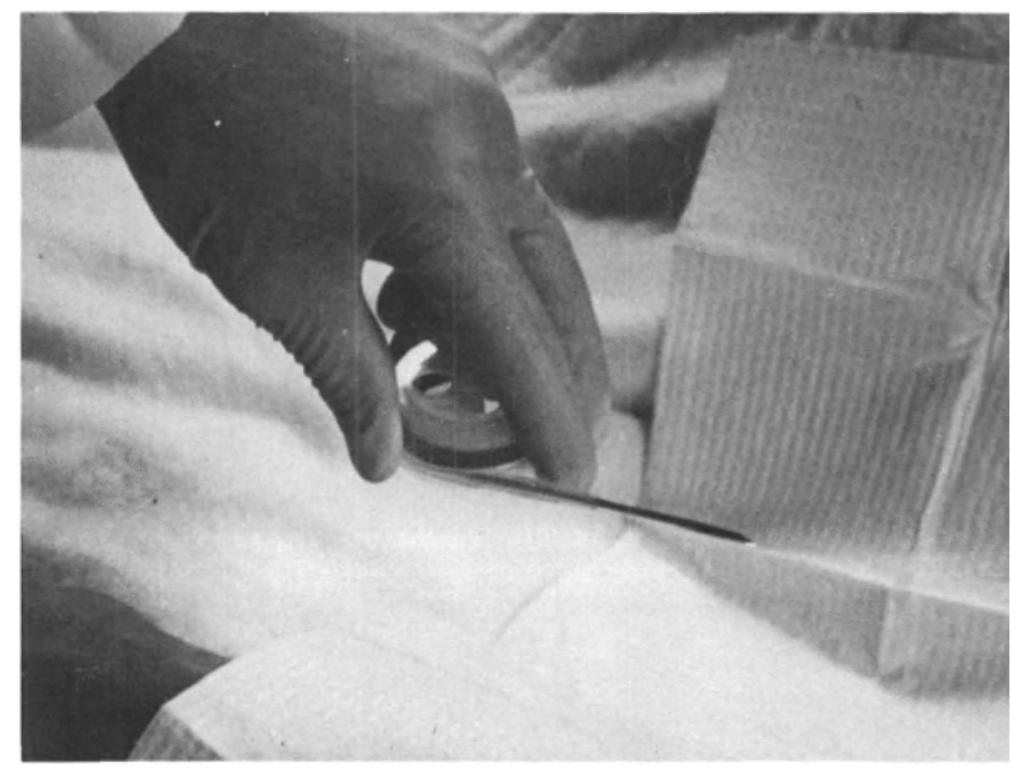

Frgune 1. The round crank unit within which is coiled the styletted silicone catheter.

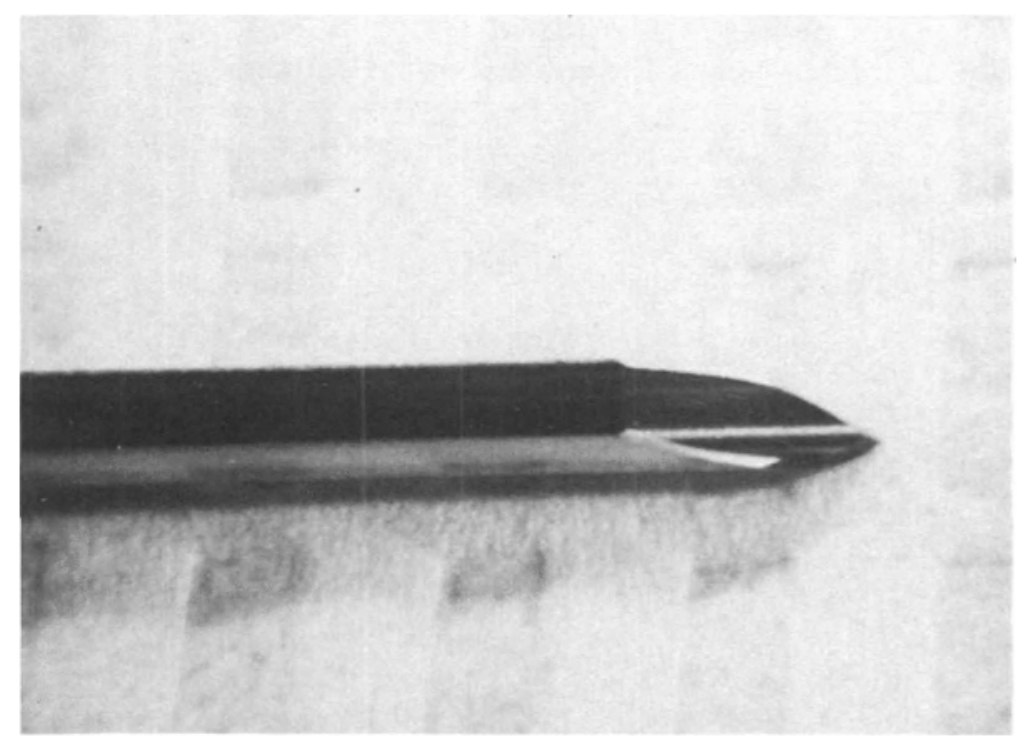

Ficure 2. The 14-gauge needle with slotted dorsum through which the catheter slides, to remove the needle.

\section{RESULTS}

The results are summarized in Tables III and IV. Use of the Butterfly needle was unpopular with both the patients and the house staff, since all the needles went interstitially, usually within three days. The incidence of phlebitis with the long polyvinyl catheters inserted through the antecubital fossa was such that most had to be removed within a few days. The average duration was six days with only 


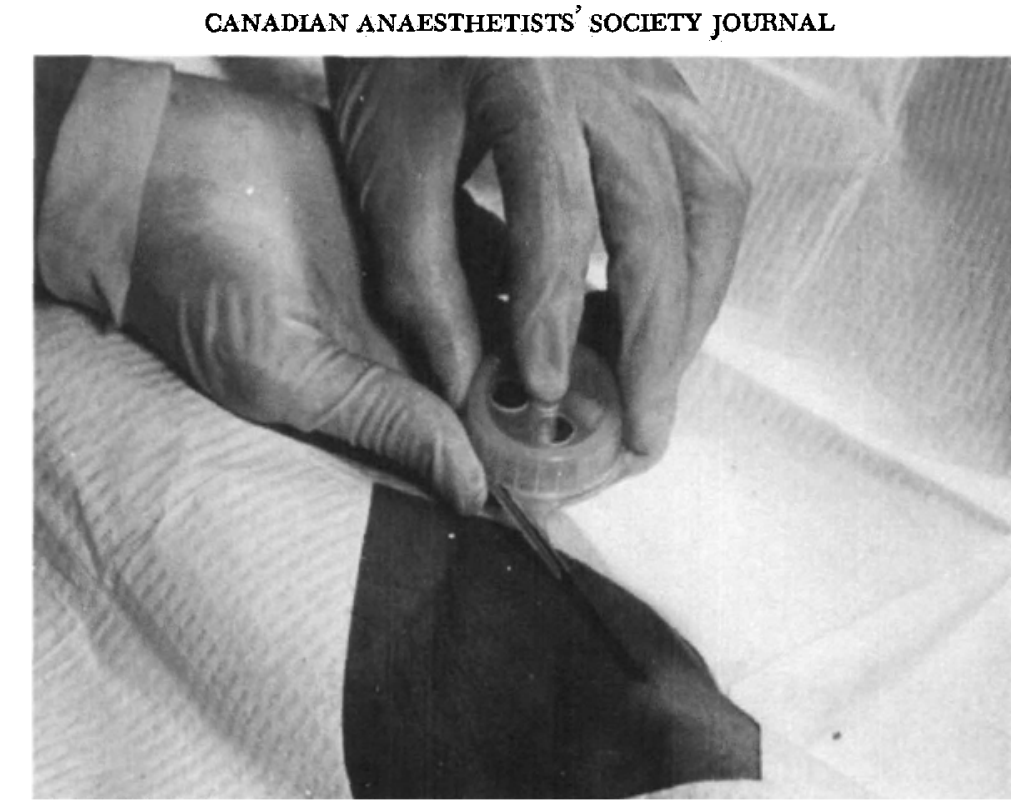

Figure 3. The crank unwinds to insert the catheter after venipuncture.

TABLE III

Duration of Stay: Intravenous Catheters

\begin{tabular}{lcc}
\hline \hline & \multicolumn{2}{c}{ No. of days in use } \\
\cline { 2 - 3 } & Average & Range \\
\hline Intrasil & 29.5 & $1-90$ \\
Centrasil & 17.5 & $3-47$ \\
Intrafusor & 6.2 & $2-17$ \\
Bard-i-cath & 15.3 & $3-51$ \\
Butterfly & 3.3 & $\mathbf{1 - 7}$ \\
\hline
\end{tabular}

4 of 20 lasting more than one week. Two patients in this group had thrombosis of the axillary vein, with oedema of the arm. One of these patients had septicaemia as a consequence of infected thrombus.

Catheters inserted through the subclavian vein were much more satisfactory, although two patients with polyvinyl catheters developed subclavian vein thrombosis and two others had septicaemia on the basis of infection at the catheter tip. The major difficulty with both the polyvinyl and the silicone elastomer catheters was their tendency to plug because of angulation at the site of cutaneous puncture. In several instances in both groups the intravenous bag was accidentally allowed to run dry.

The most satisfactory of the catheters was the peripherally-inserted, long silicone elastomer catheter (Intrasilib). Aside from a minor tendency for prolonged oozing from the puncture site, these catheters were remarkably free of trouble and their average duration exceeded 29 days. One patient had three of these catheters inserted in the same vein. The first began to leak from the catheter hub at 16 days and was immediately replaced through the same venipuncture wound by a second 


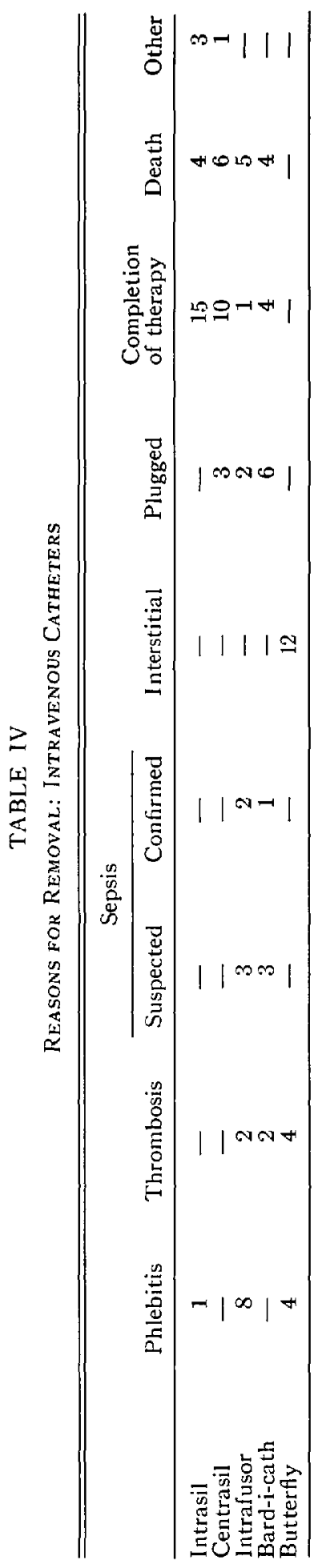


silicone catheter which was removed 51 days later at completion of therapy. One week later she was again placed on intravenous nutrition and a third silicone catheter was inserted, again using the same vein.

In this group the lack of reaction at insertion sites or along the vein was most gratifying. The only phlebitis occurred in a patient in whom a shorter catheter was used, which ended in the axillary vein. The phlebitis was undoubtedly secondary to the hypertonic infusate. In one patient receiving chemotherapy with a platelet count below $3,000 / \mathrm{mm}^{3}$, bleeding from the median basilic vein was continuous and after one hour the silicone catheter was removed. In one patient the catheter was accidentally, and in another wilfully, dislodged.

\section{Discussion}

There were no striking differences in the results between the polyvinyl and the silicone elastomer catheters inserted through the subclavian vein. The peripherally inserted silicone catheter was as good as either of the subclavian catheters and all three were clearly superior to the long peripherally inserted polyvinyl catheter or the Butterfy ${ }^{\circledR}$ needle.

There are, however, theoretical advantages to the use of the silicone catheter. Because of its softness it cannot perforate the myocardium and, unlike the polyethylene catheter, its tip is less likely to irritate the wall of the vena cava and cause a mural thrombus. ${ }^{\top}$ Silicone is non-irritating to tissues and has been shown to be much less likely to cause thrombosis than polyvinyl in experimental animals. ${ }^{8}$ Extensive experience with silicone arteriovenous shunt catheters for haemodialysis confirms the lack of thrombogenicity of silicone elastomers.

The most striking aspect of this study was the lack of venous reaction to the long silicone catheters inserted in the brachial or cephalic veins. Even after months of continuous use no evidence of thrombosis or phlebitis developed, and after removal of the catheter the veins could be used immediately for venipuncture. The only limitation to its use is the large size of the needle (14-gauge), which makes it difficult or impossible to use in many patients and particularly in those who have had their peripheral veins damaged from extensive previous intravenous infusions. In that situation the subclavian or internal jugular site for the silicone catheter is our choice.

In our view the peripherally inserted long silicone elastomer catheter is the first choice for infusions of hypertonic solutions and long term intravenous therapy in critically ill patients.

\section{Summary}

One hundred patients receiving parenteral nutrition with lipids and hypertonic amino acids and glucose were divided into five groups of 20 , depending on the type of intravenous catheter used for the infusion. Least satisfactory were the short Butterfly needles (average 3.3 days in place) and the long peripherally inserted polyvinyl central venous catheters (average 6.2 days in place). Subclavian catheters of polyvinyl (average 15.3 days) or silicone elastomer (average 17.5 days) were equally efficacious. A new long silicone elastomer catheter inserted 
peripherally was most satisfactory (average 29.5 days). Problems common with polyvinyl catheters (phlebitis, thrombosis, and sepsis) rarely occurred with either the long or short silicone elastomer catheter.

\section{RÉSUMÉ}

Un total de 100 malades sous alimentation parentérale prolongée, avec administration de lipides, d'acides aminés et de glucides, ont été divisés en cinq groupes, une aiguille ou un cathéter différent étant utilisé dans chacun des groupes.

L'aiguille d'acier "Butterfly" et les longs cathéters de polyvinyl pour insertion centrale via une veine périphérique, se sont avérés les méthodes les moins satisfaisantes, leur durée moyenne étant de 3 et de 6 pours respectivement.

L'approche sous-clavière avec un cathéter de polyvinyl (moyenne de 15.3 jours) ou en silicone (moyenne de 17.5 jours) s'est avérée beaucoup plus satisfaisante.

Un nouveau cathéter de silicone, inséré jusque dans la veine cave supérieure via une veine périphérique (basilique ou céphalique) a été le plus satisfaisant (moyenne.de 29.5 jours).

Les problèmes que l'on rencontre communément avec les cathéters de polyvinyl (phlébite, thrombose, infection) sont rares avec les cathéters de silicone courts ou longs.

\section{REFERENCES}

1. Dudnick, S.J., Wilmione, D.W., Vars, H.M., et al. Long-term total parenteral nutrition with growth, development, and positive nitrogen balance. Surgery $64: 134$ (1968).

2. Jones, M.V. \& Chaig, D.B. Venous reaction to plastic intravenous cannulae. Influence of cannula composition. Can. Anaesth. Soc. J. 19: 491 (1972).

3. Friedman, B.A. \& Jurgeleit, H.C.J. Perforation of atrium by polyethylene C.V. catheter. J. Amer. Med. Ass. 203: 1141 (1968).

4. Brown, C.A. \& KENT, A. Perforation of right ventricle by polyethylene catheter. Southern Med. J. 49: 466 (1956).

5. Walters, M.B., Strancen, H.A., \& Rotein, C.E. Complications with percutancous central venous catheters. J. Amer. Med. Ass. 220: 1445 (1972).

6. Wilmone, D.W. \& Dudrick, S.J. Safe long-term venous catheterization. Arch. Surg. 98: 256 (1969).

7. Hoshal, V.L., Anuse, R.G., \& Hoskins, P.A. Fibrin sleeve formation on indwelling subclavian central venous catheter. Arch. Surg. 102: 353 (1971).

8. Welch, G.W., McKeel, D.W., Silverstein, P., et al. The role of catheter composition in the development of thrombophlebitis. S.G. \& O. 138: 421 (1974). 